\title{
FORMATION OF ECONOMIC SELF-DETERMINATION OF SMALL BUSINESS ENTREPRENEURS
}

\author{
Tatyana A. Terekhova ${ }^{1}$, Elena L. Trofimova ${ }^{2}$, and Olesya B. Bolshakova, ${ }^{3, *}$ \\ ${ }^{1}$ Irkutsk State University, 1, K. Marx str., Irkutsk, 664003, Russia \\ ${ }^{2}$ Baikal State University, 11, Lenin str., Irkutsk, 664003, Russia \\ ${ }^{3}$ Chita Institute of Baikal State, 56, University, Anokhina str., Irkutsk, 672010, Russia
}

\begin{abstract}
The authors consider the economic self-determination of a small business entrepreneur as selfdetermination in the economic environment. The goal of economic self-determination is to achieve an optimal level of competitiveness, rational monetary attitudes and, as result, formation of economic behavior in order to achieve the set goals that contribute to the success in the professional activity. A group of 58 small business entrepreneurs took part in the survey. Preliminary, entrance testing was carried out with the use of the standardized methods, which was followed by correlation analysis. It allowed one to find out the relationship between the indicators of the scales. A group with a low level of competitiveness was identified using the standardized methodology "Attitude towards competition". As a result, the authors developed a program of group psychological counseling. The structure of the consultation process included the following stages: problem investigation, two-dimensional problem identification, planning, activity, assessment and feedback. After the group psychological counseling, the final control was carried out using the same methods and the effectiveness of this type of counseling was assessed using the Wilcoxon test. The results of mathematical and statistical analysis confirm the effectiveness of the developed program. Group psychological counseling allowed one to increase self-esteem, purposefulness, self-confidence, intensified the scenarios of economic behavior, changed the attitudes towards money and economic benefits which also ensured an increase in competitiveness indicators.
\end{abstract}

Keywords: Competitiveness, economic self-determination, group psychological counseling, small business entrepreneurs.

\section{Introduction}

Self-determination in today's economic environment is a key challenge for entrepreneurs.

Russian psychologists consider self-determination from the point of determinism, the integrity of activity, consciousness, consistency and personal development. M.G Yaroshevsky and A.V. Petrovsky defined selfdetermination as "a conscious act of defining and affirming one's position in problem situations" [9]. S.L. Rubinshtein pointed out that "self-awareness is an internal activity that gives a personality certainty and refracts outside influences" [12]; N.S. Pryazhnikov noted that self-determination is "a conscious process of analysis, acceptance and verification of the strength of one's position, as well as one's own ideas about oneself in difficult situations [10]. E.A. Klimov considers professional self-determination as one of the most important manifestations of human mental development, as a process of his inclusion in the professional community and, more broadly, in the social community [6]. According to A.L. Zhuravlev and A.B. Kupreychenko "self-determination as a search for methods of functioning and development can be simultaneously attributed to three main classes of mental phenomena, i.e. to be understood as a process, as a state (a certain cut of a process in a certain period of time) and as a property of a subject (a self-determining person or group is their special characteristic)" [15]. N.L. Ivanova believes that the process of self-determination of a person consists in choosing a certain profession, the formation of ideas about traits that help or hinder the performance of an activity [4].

The process of understanding self-determination plays an important role in the course of the personality formation of an entrepreneur. Russian researchers are convinced that a professional, unlike an ordinary performer, independently sets goals, determines the way and means to achieve them, and is also independently responsible for the consequences that have arise in the implementation of these goals.

Business psychology focuses on self-determination of the individual in social and professional terms. Subject is a person who has faced difficulties in choosing a life path. N.L. Ivanova argues that human life activity mainly depends on the results of choosing a life path and the ability to manage it [3]. In the course of her

* Corresponding author: terehovata@mail.ru 
research, she found that self-determination is directly related to self-development, self-realization, a sense of self-confidence, as well as the ability for high-quality adaptation and activity. N.L. Ivanova draws attention to the fact that self-determination is a long-term process; however, the inner core helps the individual to maintain his unity and not lose himself in a constantly changing world [3].

Economic self-determination of an entrepreneur (ESDE) of small business is considered by us (the authors of the article) as self-determination in the economic environment. The status of the ESDE system, as a system of a specific class, with a built-in metasystem level, includes the system, subsystem, component and element levels.

The metasystem level of the entreupreneur's economic self-determination system is the unity of the personal (including linguistic and cultural), socioeconomic and professional-activity metasystems [14]. Metasystems influencing the ESDE system are reflected at all its levels and primarily at the subsystem in particular, they determine the structure and content of current and potential subsystems of the phenomenon under study.

The goal of economic self-determination is to achieve an optimal level of competitiveness, monetary attitudes, which in turn form the economic behavior in order to achieve the set goals and contribute to the success in the professional activity.

R.A. Fatkhutdinov is the author of the theory of competitive advantage. According to this theory, competition is the process of a subject's leadership of personal competitive advantages in order to achieve goals, as well as victory over competitors in order to satisfy both subjective and objective needs in natural conditions or within the framework of legislation [2]

The main tool of a specialist's competitiveness is the availability of exclusive values, thanks to which the specialist has superiority over competitors and that in general constitute competitive advantages.

Competitiveness is one of the important structural components of economic self-determination, as well as one of the most important and key factors responsible for successful entrepreneurial activity. Competitiveness is considered by the authors as an integral characteristic, which includes the following properties and personality traits: high level of performance; striving for a highquality end result; stress resistance, the ability to overcome difficulties; creative attitude to business, work; striving for professional self-improvement; the ability to make responsible, sometimes risky decisions; sociability, ability to cooperate, collaborate, co-create; the ability to master a new business quickly; the ability for self-education, self-realization, self-development, etc. $[1,8,11]$.

\section{Problem Statement}

The problem of optional professional education is especially urgent for small business entrepreneurs in the context of the socio-economic crisis, aggravated by the course of the Coronavirus pandemic. It turned out that the methods used by entrepreneurs are clearly insufficient for business development in modern conditions. Retraining and advanced training for entrepreneurs are becoming fundamental for the development and maintenance of competitiveness at the current stage of development of small business in Russia.

The formation of economic self-determination of entrepreneurs is connected with 1) the development of the skill to take responsibility for his personal involvement in the activity; 2) understanding that verbalization and insight are not enough for sustainable changes.

The formation of entrepreneurs self-determination is associated with 1) practicing the ability to take responsibility for their own involvement in the activity; 2) understanding that verbalization and insight is not enough for full and sustained changes.

\section{Research Questions}

The subject of the survey is the formation of nuclear components (attitude towards competitiveness, attitude towards money) and peripheral components of economic self-determination (scenarios of economic behavior) of entrepreneurs in the process of psychological counseling.

1. The problem of the competitiveness of small business entrepreneurs is a central focus in our work. In our research we classify competitiveness as well as such subsystems as subjective characteristics of an entrepreneur, property, economic rationality, profit to the category of "nuclear", i.e. carrying meanings that contribute to the achievement of the goals of entrepreneurial activity [14].

2. The study of the monetary attitudes of entrepreneurs is the second direction in the process of the formation of economic self-determination. J. Keynes believes that the result of accumulation is the struggle between the motives of consumption and saving. The author emphasizes that a person begins to think about savings from a certain moment when his income begins to determine the level of an individual's well-being. In his opinion, an individual who is able to accumulate funds has such qualities as prudence, enterprise, craving for an independent life, prudence, discretion, the desire to leave a legacy, craving for the best [5].

3. Consequently, the study of scenarios of economic behavior of small business entrepreneurs determines the third direction of our research.

4. The forth direction is to determine the possibilities of group psychological counseling in the formation of the economic self-determination of entrepreneurs.

\section{Purpose of the Study}

The purpose of the survey is to develop and test a program of the formation of economic self-determination in the process of group psychological counseling, to prove the effectiveness of the program and show its impact on increasing the competitiveness of 
entrepreneurs, reduction the severity of negative monetary attitudes, and consolidation of the rational scenarios of economic behaviour.

\section{Research Methods}

A sample of 58 small business entrepreneurs aged from 25 to 40 (56\% of women, $44 \%$ of men) took part in the study of economic self-determination. At the stage of the preliminary survey the respondents were tested with the help of three standardized methods: attitude to competition [1], attitude to money [13], scenarios of economic behavior [7]. The processing was carried out using the methods of mathematical statistics of the IBM SPSS Statistics 17 program.

According to the results of the survey, a group of entrepreneurs with low indicators of competitiveness was identified. A psychological counseling program based on the works of $\mathrm{Yu}$. E. Aleshina and R. Kochyunas, D. Corey was developed for this group of the participants of the survey.

The training program includes 9 group consultations. Each consultation lasts 90 minutes.

The consultation process included the following stages: problem research, two-dimensional problem definition, problem identification, planning, activity, assessment and feedback (Table 1).

Table 1. Program of group psychological consulting of entrepreneurs

\begin{tabular}{|c|c|c|c|}
\hline Title of the block & Aim & $\begin{array}{c}\text { Psychological methods, procedures } \\
\text { and techniques }\end{array}$ & $\begin{array}{c}\text { Number of } \\
\text { meetings }\end{array}$ \\
\hline Analyzing the problem & $\begin{array}{l}\text { Acquaintance. At this stage the } \\
\text { contact is established and mutual } \\
\text { trust is achieved. }\end{array}$ & $\begin{array}{l}\text { Analytical (conversation, observation); } \\
\text { procedures and techniques: provision of } \\
\text { information; reflective listening, } \\
\text { paraphrasing and summarizing; } \\
\text { approval and calming, verbal and non- } \\
\text { verbal communication techniques. }\end{array}$ & 1 \\
\hline $\begin{array}{l}\text { Two-dimensional problem } \\
\text { identification }\end{array}$ & $\begin{array}{l}\text { To characterize accurately the } \\
\text { client's problem, find out } \\
\text { cognitive and emotional aspects. }\end{array}$ & $\begin{array}{l}\text { Analytical (conversation, observation); } \\
\text { techniques of verbal and non-verbal } \\
\text { communication; reception } \\
\text { paraphrasing, encouragement to deep } \\
\text { research of the problems that have } \\
\text { arisen, analysis of feelings, statements. }\end{array}$ & 1 \\
\hline Alternatives identification & $\begin{array}{l}\text { To find out and openly discuss } \\
\text { possible alternatives of the ways } \\
\text { to solve the problems related to } \\
\text { the development of economic } \\
\text { self-determination of the } \\
\text { entrepreneurs. }\end{array}$ & $\begin{array}{l}\text { Analytical (conversation, observation); } \\
\text { procedures and techniques: reflective } \\
\text { listening; reflection of content } \\
\text { (paraphrasing and generalization), } \\
\text { confrontation. }\end{array}$ & 1 \\
\hline Planning & $\begin{array}{l}\text { Critical assessment of the chosen } \\
\text { alternatives. Making a plan of } \\
\text { the realistic problem solving. }\end{array}$ & $\begin{array}{l}\text { Analytical (conversation, observation); } \\
\text { procedures and techniques: providing } \\
\text { information; paraphrasing and } \\
\text { summarizing. }\end{array}$ & 1 \\
\hline Activity & $\begin{array}{l}\text { Consistent implementation of } \\
\text { the problem-solving plan. } \\
\text { Psychological counseling. } \\
\text { As well as independent use of } \\
\text { the acquired knowledge, skills } \\
\text { and abilities for the development } \\
\text { of economic self-determination. }\end{array}$ & $\begin{array}{l}\text { Analytical (conversation observation), } \\
\text { developmental (training exercises), } \\
\text { modeling (role-playing games). }\end{array}$ & 2 weeks \\
\hline Assessment and Feedback & $\begin{array}{l}\text { Assessment of the current level } \\
\text { of goal achievement and } \\
\text { generalization of the achieved } \\
\text { results. }\end{array}$ & $\begin{array}{l}\text { Analytical (conversation and } \\
\text { observation), testing. }\end{array}$ & 1 \\
\hline
\end{tabular}

It should be added that the entire process of psychological counseling was carefully structured. The stages of counseling were distinguished, the results were assessed and information on the counseling process was provided. We discussed the results and formulated conclusions with the clients after each stage and then proceeded to the next stage of consulting. Different techniques of verbal and non-verbal communication were used during the process of psychological counseling.

The main tasks that the authors faced in the process of group psychological counseling:
1. Generating an atmosphere of respect and trust. One of the keys of successful counseling is helping a client to feel acceptance, understanding and sympathy from the counselor psychologist.

2. Providing participants with all the information about the group process and on how to get the most out of the group work. Explaining the goals of the group, guiding the group members into the structure of the session and informing them about the necessity of active actions. Discussing their expectations with clients and encouraging them to make assumptions about who and what the group can benefit from. 
3. Creating a system for assessing the problems of group members. In this work, there was a multimodal assessment that included such areas as behavior, feelings, thinking, interpersonal relationships, etc.

4. Consolidating the skills of new behavior acquired by the members of the group and keeping control of them so that they gradually become aware of every, even a very small achievement.

5. Training the group members to take responsibility for their own involvement in different types of activity, both within the group and outside it. Helping clients understand in the process of psychological counseling that verbalization and insight are not enough for meaningful and sustainable change. Expanding their repertoire of adaptive behaviors, group members experiment with their own behaviors during the session and while doing their homework.

6. Helping team members prepare for the completion of the work. Supporting clients if it is necessary when there is time for discussing their reactions, integrating the gained experience and practicing the acquired skills necessary for effective functioning outside the group.

\section{Findings}

We determined the level of respondents' competitiveness using the "attitude to competition" methodology. According to the results of the study, $48 \%$ of respondents showed a low level of competitiveness. Therefore, a preliminary empirical study and further development of a program for the formation of economic self-determination of small business entrepreneurs was carried out in a group of respondents with a low level of competitiveness.

The results of the study of scenarios of economic behavior are presented in Figure 1.

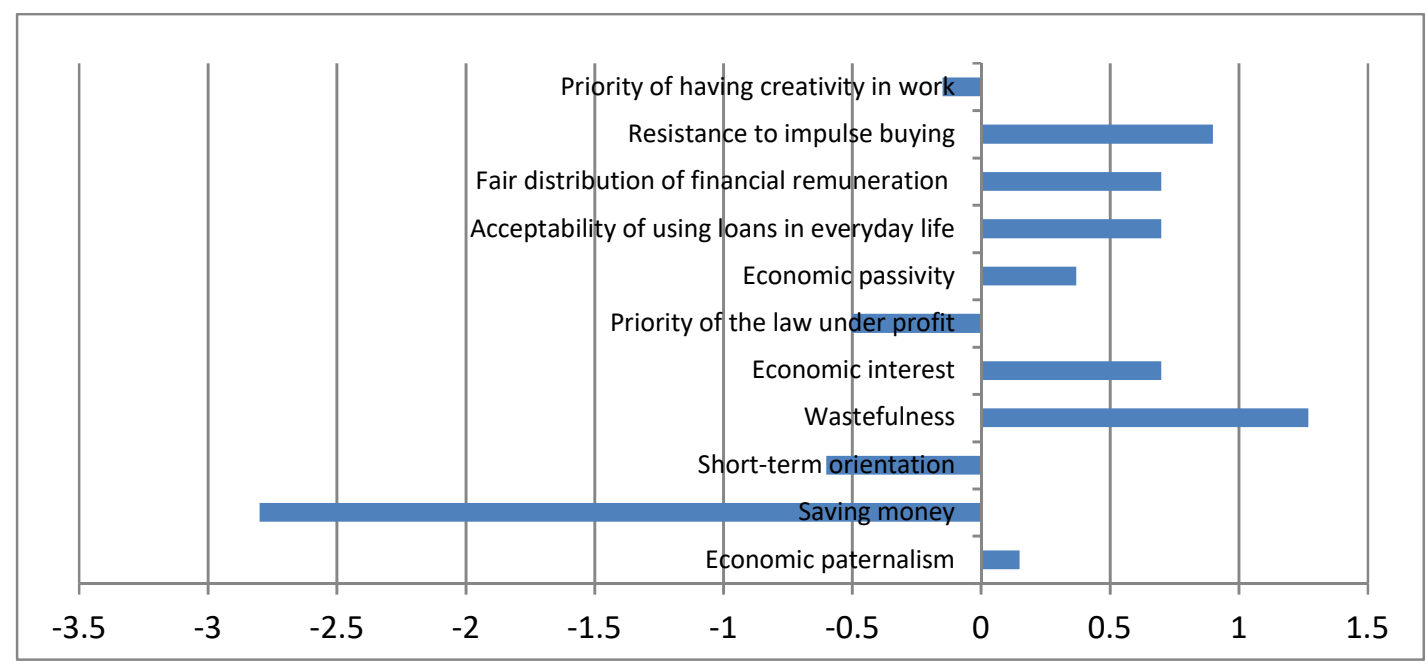

Figure 1. Results of the study of scenarios of economic behavior

Figure 01 shows the prevailing scenarios of economic behavior: "saving money", "wastefulness", "short-term orientation in economic behavior", "economic passivity", "economic paternalism". This type of behavior can be characterized as a dismissive and irrational attitude towards money, underestimation of the importance of time perspectives in doing business, an orientation towards making quick profits and achieving short-term prospects. At the same time, there are such scenarios as "economic interest", "acceptability of using loans in everyday life", "fair distribution of financial rewards" and "resistance to impulse buying" that indicates the involvement and orientation of the respondents to entrepreneurial activity. The "priority of law over profit" scenario indicates a preference for compliance with the legality of activities. An interesting indicator, although not high, was "the priority of having creativity in work". This result indicates the importance of focusing on the process, and not only on the result (profit) in one's activity. We can say that entrepreneurs who are not interested in competition are passive in their professional activities and do not focus on obtaining and increasing their profits. An uncompetitive entrepreneur is more inclined to focus on solving short-term and everyday tasks with a guaranteed, although not high, profit.

Figure 2 presents attitudes towards money of respondents with a low level of competitiveness.

Taking into account the low level of attitude towards competition, we can assume that dissatisfaction with their financial situation provokes an increased focus on money and related topics. Money is an emotionally meaningful object for them and it takes up their thoughts and attention. On the one hand, they carefully control their finances, but on the other hand, such entrepreneurs willingly take risks due to the high importance of money. They value money and often overestimate its value. In such cases, money can be a symbol of independence and power as well as an instrument for controlling others.

Further, a correlation analysis was carried out to study the relationship between competitiveness, attitudes towards money and scenarios of economic behavior of entrepreneurs (tables 2, 3). 


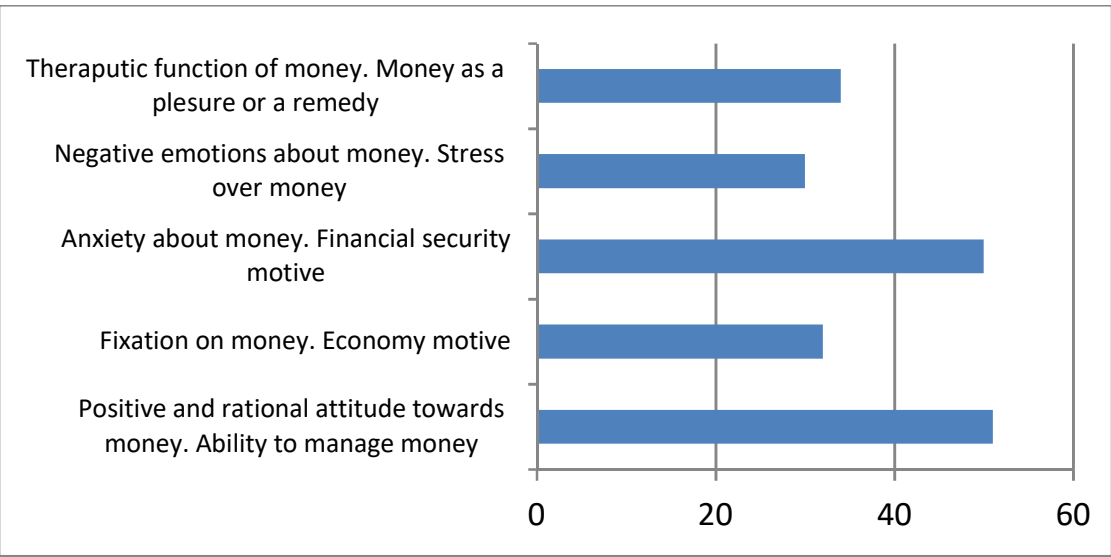

Figure 2. Results of the study of the attitude to money of entrepreneurs with low indicators of attitude to competition

Table 2. Program of group psychological consulting of entrepreneurs

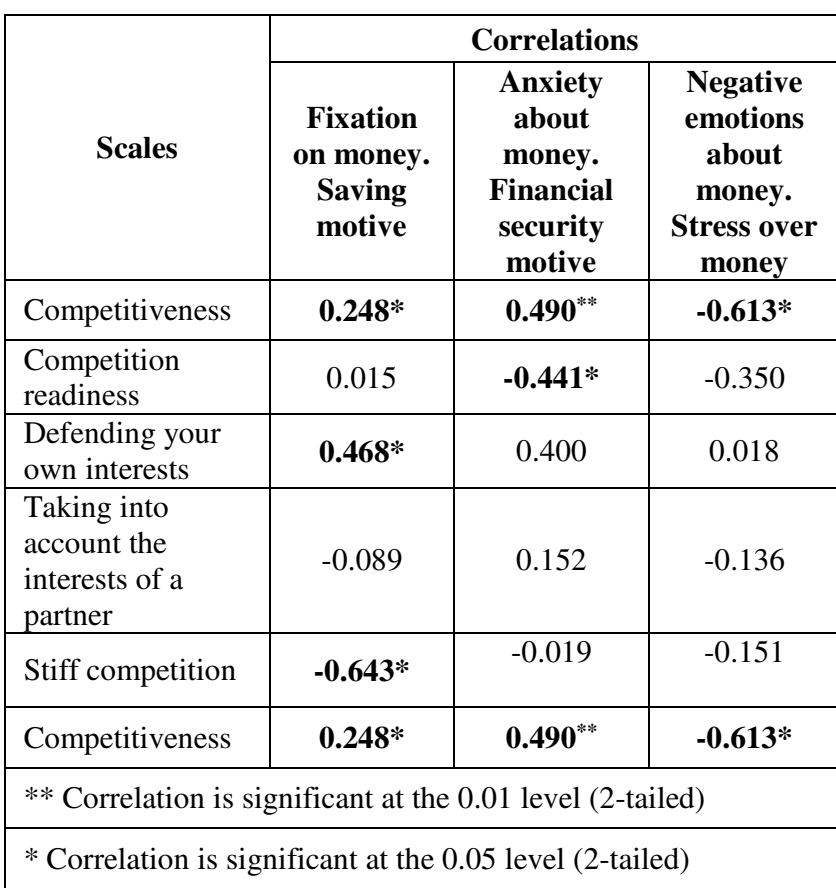

Correlation analysis showed significant interrelation between almost all indicators of competitiveness, except for "taking into account the interests of the partner" and monetary attitudes.

Thus, the "competitiveness" scale correlates with the following scales: "fixation on money, the motive for saving" $(\mathrm{r}=0.248, \mathrm{p}=0.05)$, "anxiety about money" $(\mathrm{r}=0.490, \mathrm{p}=0.001)$, as well as with scale "negative emotions towards money" $(\mathrm{r}=-0.613, \mathrm{p}=0.02)$. That is, entrepreneurs who demonstrated a low level of attitude to competition show negative emotions towards money, and experience tension and anxiety about money. The higher the level of competitiveness, the sooner they will be guided by the motive of financial security and saving money in their activities. In this case, there is a desire to save money in case of unforeseen circumstances in order to reduce financial risks. The scale "defending one's interests" also correlates with the motive for saving $(\mathrm{r}=0.468, \mathrm{p}=0.06)$.
The indicator of "readiness to compete" has an inverse relationship with "anxiety about money" ( $r=-0.441, p=0.03$ ), i.e., the lower the readiness to compete, the higher the anxiety about money. Here we can say that there is a frequent anxiety about money. When you need to invest a large amount or make an expensive purchase, they take a long time to make a decision, often get nervous, worried.

The "Stiff competition" scale has an inverse correlation with the "fixation on money, economy motive" scale $(r=-0.643, p=0.013)$. In conditions of stiff competition, the subjects are not focused on saving money but the lower the readiness for tough actions, the more they value money, often overestimating its significance.

There are no interrelations between competitiveness indicators and monetary attitudes such as a rational attitude to money and getting pleasure from money in this sample.

The analysis of correlations between indicators of attitude to competition and scenarios of economic behavior also demonstrated some significant connections (Table 3).

The lower the level of competitiveness of entrepreneurs, the more they demonstrate economic passivity $(\mathrm{r}=0.622, \mathrm{p}=0.034)$ and wastefulness $(\mathrm{r}=0.588, \mathrm{p}=0.027)$. A positive correlation was found between the "Willingness to compete" scale and the choice of long-term or short-term orientation of economic behavior $(r=0.604, p=0.022)$ and the priority of profit or law. So, an entrepreneur with a low readiness for competition is focused on quick results and profit, as well as on the priority of the law over profit $(r=0.724$, $\mathrm{p}=0.033$ ).

Correlations were also revealed between the scales "Taking into account the interests of a partner" and "Economic paternalism" $(\mathrm{r}=0.544, \mathrm{p}=0.044)$. Entrepreneurs showing a low level of partner orientation tend to demonstrate a narrow perspective, limited interests, seeking patronage and a system of additional benefits, subsidies and payments for themselves.

The scales "Stiff competition" and "economic activity/passivity" ( $r=0.632, \mathrm{p}=0.015)$ have a positive correlation, it means that if competition decreases, economic passivity also grows. 
Table 3. Program of group psychological consulting of entrepreneurs

\begin{tabular}{|c|c|c|c|c|c|}
\hline \multicolumn{6}{|c|}{ Correlations } \\
\hline Scales & $\begin{array}{c}\text { Economic } \\
\text { independence/ } \\
\text { economic } \\
\text { paternalism }\end{array}$ & $\begin{array}{c}\text { Long-term/ } \\
\text { short-term } \\
\text { orientation on } \\
\text { economic behavior }\end{array}$ & $\begin{array}{c}\text { Economy/ } \\
\text { wastefulness }\end{array}$ & $\begin{array}{l}\text { Priority of profit over } \\
\text { the law/ Priority of the } \\
\text { law over profit }\end{array}$ & $\begin{array}{l}\text { Economic } \\
\text { activity/ } \\
\text { Economic } \\
\text { passivity }\end{array}$ \\
\hline & -0.062 & 0.139 & 0.588* & -0.480 & $0.622^{*}$ \\
\hline Competitiveness & -0.127 & $0.604^{*}$ & 0.360 & $0.724^{*}$ & -0.368 \\
\hline Competition readiness & 0.085 & 0.100 & 0.445 & 0.082 & 0.209 \\
\hline $\begin{array}{l}\text { Defending your own } \\
\text { interests }\end{array}$ & $0.544^{*}$ & -0.112 & -0.040 & -0.085 & -0.273 \\
\hline $\begin{array}{l}\text { Taking into account the } \\
\text { interests of a partner }\end{array}$ & -0.037 & -0.167 & 0.050 & -0.385 & $0.632^{*}$ \\
\hline
\end{tabular}

The final stage of the psychological counseling program was aimed at processing and evaluating the effectiveness of the program and was based on the results of the data obtained before and after the group psychological counseling. At this stage, exit psychological testing was carried out. It also included the discussion of the results of the participants' independent work on the formation of economic selfdetermination.

For this purpose, the average values of the indicators of the attitude to competition were calculated before and after the training (Figure 03).

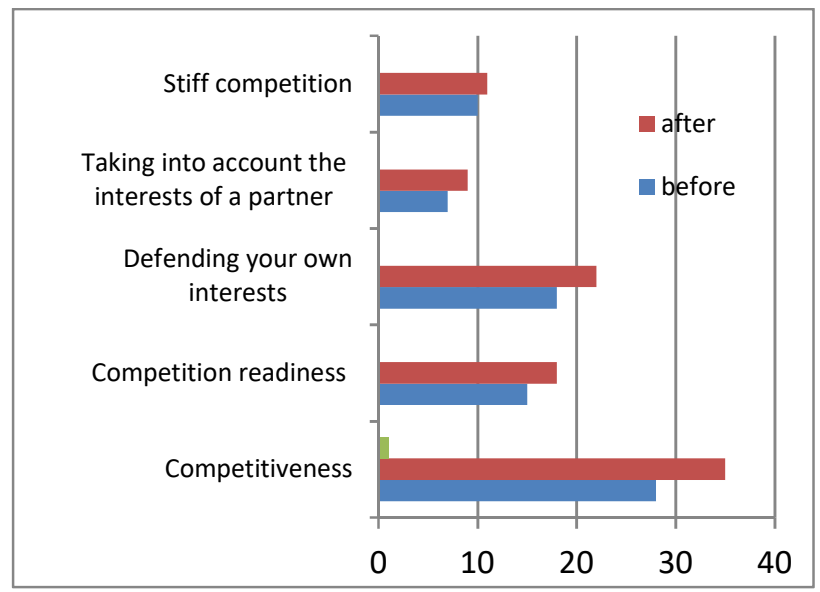

Figure 3. Comparison of results before and after group psychological counseling in terms of attitudes towards competition

Figure 3 shows that the indicators of "attitude to competition" have increased. These changes are due to the fact that during the program the emphasis was placed on the development of positive self-esteem and such qualities as self-confidence, purposefulness, communication, independence, responsibility, determination.

The entrepreneurs managed to form an attitude that competition is a stimulating factor for development and promotion both in personal and professional activities, and as the test results show, entrepreneurs began to assess their competitiveness more positively (the value is above average).
The results of mathematical and statistical analysis according to Wilcoxon's criterion confirm that there are significant differences in the scales of "competitiveness" ( $\mathrm{p}=0.024)$, "defending one's interests" $(\mathrm{p}=0.023)$, "taking into account the interests of a partner" $(p=0.014)$ and "stiff competition" $(p=0.020)$. No significant differences were found on the "competition readiness" scale.

As for the monetary indicators, we can also see changes of all the indicators (Figure 04).

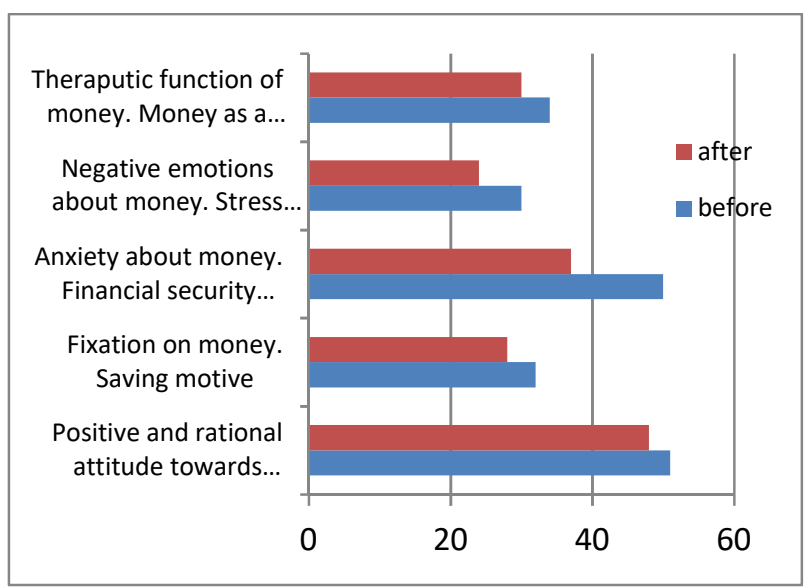

Figure 4. Comparison of the results by monetary attitudes before and after group psychological counseling

We can see a decent on all scales, this can be characterized as a decrease in anxiety about money, there is no fixation on money and a change in the motive for saving to the motive for financial security, thus the neutral or positive attitude in relation to money was formed.

The Wilcoxon signed-rank test showed the differences on the scales "fixation on money" $(\mathrm{p}=0.010)$, "anxiety about money" $(\mathrm{p}=0.042)$, and "negative emotions towards money" ( $\mathrm{p}=0.049)$, questionnaire "Relationship to money." No significant differences were found on the scales "positive and rational attitude to money" and "therapeutic function of money, money as pleasure".

The results of scenarios of economic behavior also demonstrate changes (Table 4). 
Table 4. Results of the test "Scenarios of economic behavior" before and after group psychological counseling

\begin{tabular}{|c|c|c|c|c|c|c|c|c|c|c|c|c|c|}
\hline \multicolumn{14}{|c|}{ Mean } \\
\hline scenario & -3 & $-2,5$ & -2 & -1 & $-0,5$ & $\mathbf{0}$ & 0,5 & 1 & 1,5 & 2 & 2,5 & 3 & scenario \\
\hline $\begin{array}{c}\text { Economic } \\
\text { independence }\end{array}$ & & & & $-1,8$ & & 0,07 & & & & & & & $\begin{array}{l}\text { Economic } \\
\text { paternalism }\end{array}$ \\
\hline Saving money & $-2,9$ & & & & & $\longrightarrow$ & & 1 & & & & & Saving time \\
\hline $\begin{array}{c}\text { Short-term } \\
\text { orientation } \\
\text { (perspective) in } \\
\text { economic behavior }\end{array}$ & & & & & $-0,6$ & & & & $\rightarrow$ & 2,1 & & & $\begin{array}{c}\text { Long-term } \\
\text { orientation } \\
\text { (perspective) in } \\
\text { economic behavior }\end{array}$ \\
\hline Economy & & & & & & & 0,7 & & 1,2 & & & & Wastefulness \\
\hline $\begin{array}{l}\text { Economic } \\
\text { indifference }\end{array}$ & & & & & & & 0,7 & & $\overrightarrow{1,4}$ & & & & Economic interest \\
\hline $\begin{array}{c}\text { Priority of the law } \\
\text { under profit }\end{array}$ & & & & & $-0,5$ & $-0,3$ & & & & & & & $\begin{array}{l}\text { Priority of profit } \\
\text { under the law }\end{array}$ \\
\hline Economic activity & & & & $-1,4$ & & 0,36 & & & & & & & $\begin{array}{l}\text { Economic } \\
\text { passivity }\end{array}$ \\
\hline $\begin{array}{l}\text { Refusal to use loans } \\
\text { in everyday life }\end{array}$ & & & & & & & 0,7 & & 1,2 & & & & $\begin{array}{l}\text { Acceptability of } \\
\text { using loans in } \\
\text { everyday life }\end{array}$ \\
\hline $\begin{array}{l}\text { Equal distribution of } \\
\text { financial reward }\end{array}$ & & & & & & & 1 & & 1,3 & & & & $\begin{array}{l}\text { Fair distribution of } \\
\text { financial reward }\end{array}$ \\
\hline $\begin{array}{l}\text { Addiction to impulse } \\
\text { buying }\end{array}$ & & & & & & & 1 & & & 2 & & & $\begin{array}{l}\text { Resistance to } \\
\text { impulse buying }\end{array}$ \\
\hline $\begin{array}{l}\text { Priority of having } \\
\text { creativity in work }\end{array}$ & & & & & $-0,4$ & $-0,07$ & & & & & & & $\begin{array}{c}\text { Priority of the } \\
\text { amount of reward }\end{array}$ \\
\hline
\end{tabular}

Significant changes can be seen in the scenarios "saving money". It changed to the polar one "saving time", "economic paternalism" was replaced by "economic independence", "orientation to the short-term perspective in economic behavior" changed to "longterm orientation (perspective ) in economic behavior", and "economic passivity" was replaced by "economic activity". Entrepreneurs see the prospect of developing their business and are ready to invest into the future in order to increase their income. They are ready to act and be active.

In comparison with the indicators before testing, entrepreneurs now prefer saving their time rather than money, this approach indicates the value of their own time and effort, rational use of time and financial resources.

As for the "wastefulness" scenario, its indicators decreased towards "economy". The indicators of the scenarios "economic interest," "acceptability of using credit in everyday life," "fair distribution of financial rewards," "resistance to impulse purchases," and "priority of creativity in work," increased. The indicator of the scenario "priority of law over profit" changed its value to the neutral. And it is quite interesting.

The Wilcoxon signed-rank test showed significant differences in the indicators of the "Scenarios of Economic Behavior" practically for all scales, except three of them "Priority of profit under the law - priority of the law under profit", "Economic activity - passivity", "Distribution of financial rewards by equality - by fairness". Significant changes took place according to the following scenarios: "Economic paternalism" was replaced by "economic independence", "saving money" was replaced by "saving time", "wastefulness" decreased towards "economy". The scenarios "acceptability of using loans in everyday life", "short-term versus longterm orientation in economic behavior", "non-impulse buying", "priority of creativity in work" and "economic interest" have significantly increased.

Thus, the results of mathematical and statistical analysis show positive changes in the scales of competitiveness, scenarios of economic behavior, and attitude to money and it proves the effectiveness of the program of group psychological counseling.

\section{Conclusion}

The economic self-determination of a small business entrepreneur is viewed from the perspective of a metasystem approach.

The system of economic self-determination of an entrepreneur is influenced by more than one metasystems. The main ones are personal (with built-in linguo-cultural), socio-economic and professional activity.

Competitiveness is viewed as one of the "nuclear" subsystems in the structure of economic selfdetermination of an entrepreneur and the key factor that contributes to business success.

The results of the empirical research showed that $48 \%$ of the surveyed small business entrepreneurs are characterized by the low level of competitiveness. 
Entrepreneurs with a low level of competitiveness do not find links between the ability to manage money rationally and competitiveness. The lower the level of competitiveness, the sooner money evokes negative emotions, but at the same time there is no desire to save money and ensure financial security, and the more inherent a strategy of waste. These respondents are probable experiencing financial difficulties and cannot afford to use their money for pleasure they mostly spend it on basic urgent needs.

Entrepreneurs with a low level of competitiveness are more likely to show economic passivity, tend to be lawabiding and normative, and choose more stable types of business, with government support or other guarantees of regular income. Such entrepreneurs are characterized by an orientation towards short-term scenarios of economic behavior, quick results, and long-term prospects are not considered attractive and profitable.

Formation of the components of economic selfdetermination of small business entrepreneurs is possible in the process of psychological counseling, using analytical, developmental and modeling technologies.

Group psychological counseling made it possible to increase self-esteem, purposefulness, self-confidence, indicators of competitiveness, develop effective scenarios for economic self-determination and change attitudes towards money.

The results of mathematical and statistical analysis show positive changes in the structural components of economic self-determination and prove the effectiveness of the developed program.

\section{Acknowledgments}

The work was supported by grant 19-013-00430 A of the Russian Foundation for Basic Research.

\section{References}

1. O.S. Deineko. Economic psychology. (Publ. house of St. Peter. Univ., St. Petersburg, 2020)

2. R.A. Fatkhutdinov. Management of the competitiveness of the organization (Eksmo Publ. House, Moscow, 2015)

3. N.L. Ivanova. New perspectives of the business psychology. Organiz. Psychol., 10, 208 (2020)

4. N.L. Ivanova, V.A. Shtroo, N.V. Antonova. Business Psychology (Yurait, Moscow, 2016)

5. J. Keynes. The general Theory of Employment, Interest \& Money (Yurait, Moscow, 2018)

6. E. Klimov. Psychology of labour, engineeraing psychology and ergonomics (Publ. Center "Acad.", Moscow, 2015)

7. N. Lebedeva, A. Tatarko. Relationship of values and assessments of situations of social and economic behavior. Mat. of 11 Int. sci. and pract. Conf. Economic psychology: topical theoretical and applied problems (Irkutsk, 2010), pp. 96-102
8. K. Mikulchik. Assessment of the competitiveness of the personnel of the enterprise. Young sci., 5, 370372 (2016)

9. A. Petrovsky, M. Yaroshevsky. Fundamentals of theoretical psychology. (INFRA, Moscow, 1998)

10. N. Pryazhnikov. Social and professional selfdetermination of personality in humanitarian and economic education: perspectives and development (Publ. Cent. "Rus. Econ. univ.”, Moscow, 2015)

11. S. Reznik. Foundations of personal competitiveness (INFRA, Moscow, 2019)

12. S. Rubinshtein. Fundamentals of General Psychology (Publ. House "AST", Moscow, 2020)

13. M. Semenov. Questionnaire for studying the attitude of schoolchildren to money (CAS Print. Cent., Omsk, 2009)

14. T. Terekhova, E. Trofimova (2019). Economic selfdetermination of an entrepreneur in the context of a metasystem approach. News of Irk. State Univ., Ser. Psychol., 30, 68-82. DOI: http:// doi.org/10.26516/2304-1226.2019.30.68

15. A. Zhuravlev, A. Kupreychenko. Economic SelfDetermination: Theory and Empirical Research. (Publ. house Inst. of Psychol. RAS, Moscow, 2007) 